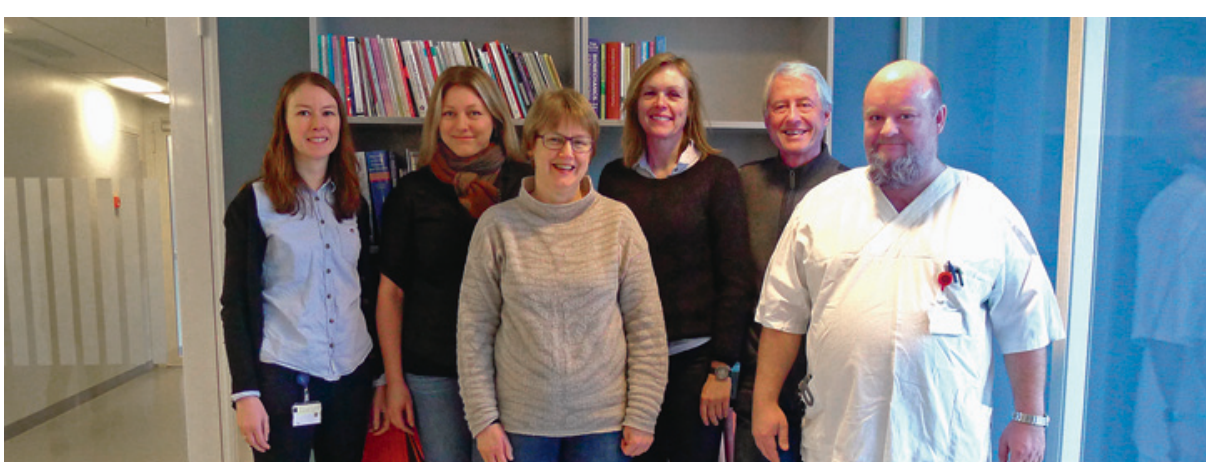

Fra venstre Kristin Taraldsen, Pernille Thingstad, Ingvild Saltvedt, Jorunn L. Helbostad, Olav Sletvold og Anders Prestmo. Foto: Kristina Jones, Norges teknisk-naturvitenskapelige universitet

\title{
Samarbeid mellom ortoped og geriater er viktig ved hoftebrudd
}

Kombinasjonen av ortopedisk og geriatrisk behandling gir bedre funksjon og er kostnadseffektivt sammenliknet med standardbehandling ved hoftebrudd. Dette viser en ny, norsk studie.

Hvert år pådrar mange tusen pasienter i Norge seg et hoftebrudd. Mange av disse pasientene er gamle og skrøpelige og har mange andre sykdommer. Ofte vil hoftebruddet føre til et betydelig redusert funksjonsnivå, og dødeligheten er høy. Såkalte ortogeriatriske behandlingsmodeller, dvs. der tverrfaglige geriatriske team og ortopeder samarbeider om behandlingen, har vært tradisjon bl.a. i Storbritannia i mange år. Forskning har vist lovende resultater, men det mangler forskning der det tverrfaglige teamet starter behandlingen allerede fra innkomst i sykehuset og der man ser på langtidseffekter og helseøkonomi.

I The Trondheim Hip Fracture Trial ble hjemmeboende og gangføre hoftebruddspasienter over 70 år randomisert $\mathrm{i}$ akuttmottaket til vanlig behandling ved ortopedisk avdeling $(n=199)$, eller til ortogeriatrisk behandling i en geriatrisk sengepost $(\mathrm{n}=198)$ (1). Kirurgisk behandling ble utført av de samme ortopedene i begge grupper. I ortogeriatrisk gruppe fikk pasientene bred geriatrisk utredning og behandling ved et tverrfaglig team. Det ble lagt vekt på kartlegging av somatisk, mental og sosial status og funksjonsnivå både før bruddet og under sykehusoppholdet. Tidlig mobilisering og rehabilitering sto sentralt, og utreiseplanlegging startet så tidlig som mulig.

Fire og 12 måneder etter bruddet var det i favør av ortogeriatrigruppen statistisk signifikante og klinisk betydningsfulle forskjeller i mobilitet, aktiviteter i dagliglivet (IADL- og ADL-funksjoner), livskvalitet og frykt for å falle. Liggetiden i ortogeriatrisk gruppe var 1,7 dager lenger enn i ortopedisk gruppe, men en firedel av ortogeriatripasientene kunne skrives ut direkte til hjemmet, sammenliknet med kun en tidel av ortopedipasientene. I det påfølgende året etter hoftebruddet hadde de ortogeriatriske pasientene færre liggedøgn i sykehus, sykehjem og rehabiliteringsinstitusjoner.

- Studien viser at ortogeriatriske behandlingsmodeller gir bedre resultater og er kostnadseffektive sammenliknet med tradisjonell ortopedisk behandling, sier Ingvild Saltvedt, som er studiens sisteforfatter. - All rutinebehandling av hoftebruddpasienter i Norge bør skje i samarbeid mellom ortopeder og geriatere, sier Saltvedt.

\section{Tverrfaglig forskningssamarbeid}

Studien utgår fra forskningsgruppe for geriatri, slag og bevegelse ved Institutt for nevromedisin ved Norges teknisk-naturvitenskapelige universitet (NTNU). Gruppen, ledet av professor Jorunn L. Helbostad, har tidligere gjennomført studier på helsetjenesteforskning, geriatri, slag, bevegelsesvansker og fall hos eldre. Olav Sletvold, som er professor og avdelingsoverlege ved Avdeling for geriatri ved St. Olavs hospital, var prosjektleder. Førsteforfattere er Anders Prestmo (lege) og Gunhild Hagen (helseøkonom), som begge er ph.d.-stipendiater. Andre medforfattere er Lars Gunnar Johnsen, Kristin Taraldsen, Turi Saltnes, Pernille Thingstad, Vidar Halsteinli og Stian Lydersen. Leder av Clinical Trials Unit ved Oxford University, professor Sarah Lamb har vært aktiv deltaker i forskningsgruppen.

\section{Lise Mørkved Helsingen}

Tidsskriftet

\section{Litteratur}

1. Prestmo A, Hagen G, Sletvold O et al. Comprehensive geriatric care for patients with hip fractures: a prospective, randomised, controlled trial. Lancet 2015; e-publisert 4.2.2015.

\section{Ordforklaring}

Ortogeriatri: Et samarbeid mellom ortopeder og tverrfaglig geriatrisk team. Bred geriatrisk utredning og behandling er en tverrfaglig arbeidsmetode som benyttes ved geriatriske sengeposter. Metoden er vist å gi bedre behandlingsresultater hos geriatriske pasienter med og uten brudd.

\section{THE LANCET}

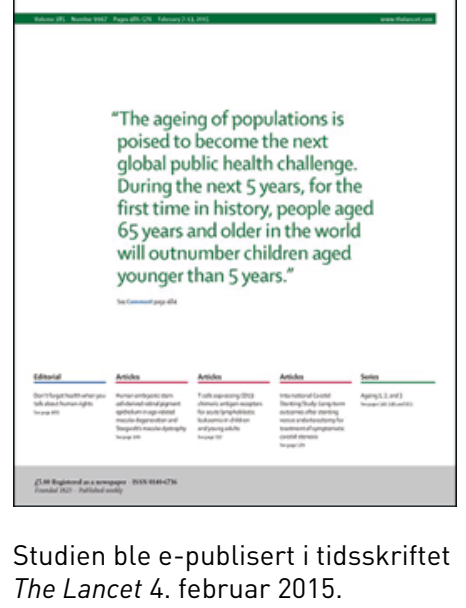

